pag

Business School

WORKING PAPER SERIES

Working Paper

2014-218
R\&D investments and high-tech firms' stock return volatility

Sami Gharbi

Jean-Michel Sahut

Frédéric Teulon

http://www.ipag.fr/fr/accueil/la-recherche/publications-WP.html

IPAG Business School

184, Boulevard Saint-Germain

75006 Paris

France

IPAG working papers are circulated for discussion and comments only. They have not been peer-reviewed and may not be reproduced without permission of the authors. 


\title{
R\&D investments and high-tech firms' stock return volatility
}

\author{
Sami Gharbi a, b, 1 \\ sami_gharbi@yahoo.fr \\ Jean-Michel Sahut ${ }^{\mathrm{c}, *}$ \\ jmsahut@gmail.com \\ Frédéric Teulon ${ }^{c, 2}$ \\ f.teulon@ipag.fr
}

\author{
${ }^{a}$ University of Jendouba, - and Cerege EA 1722 University of Poitiers 20, rue Guillaume VII \\ le Troubadour BP 639-86022 PoitiersTunisia \\ ${ }^{\boldsymbol{b}}$ Cerege EA 1722-20, University of Poitiers, rue Guillaume VII le Troubadour, BP 639- \\ 86022 Poitiers, France \\ ${ }^{c}$ IPAG Business School Paris, IPAG, 184 Boulevard Saint-Germain, 75006 Paris, France \\ ${ }^{*}$ Corresponding author. Tel.: + 33651032488. \\ ${ }^{1}$ Tél.: + 33549454499 . \\ ${ }^{2}$ Tél.: + 33153633600 .
}

\begin{abstract}
The empirical evidence suggests that firms in high-tech industries exhibit high stock return volatility. In this paper, we conceive of the $R \& D$ investment intensity as a possible explanation for the stock volatility behavior in these industries. We suggest that $R \& D$ activities generate information asymmetry about the prospects of the firm and make its stock riskier. Relying on Panel data models, we investigate this relationship for French high-tech firms. We find out a strong positive relationship between stock return volatility and $R \& D$ investment intensity. This finding suggests that R\&D intensive firms should implement an efficient information disclosure policy to reduce information asymmetry and to avoid excessive stock return volatility.
\end{abstract}

Keywords: R\&D; Idiosyncratic idiosyncratic volatility; Riskrisk; Asymmetric asymmetric information; Stock stock return; Innovationinnovation; Highhigh-tech firms 


\section{Introduction}

Stock return volatility is a widely used measure of risk both in financial theory and practice. Stock return volatility is varying across time and firms. The investigation of the determinants of stock return volatility still forms an attractive research area.

Shiller [1] indicates that stock prices change so much that they cannot be merely explained by fluctuations in dividends or earnings. Schwert [2] finds little evidence that macroeconomic factors can explain stock market volatility movements.

Campbell, Lettau, Malkiel and Xu [3] provide formal empirical evidence that US idiosyncratic stock volatility has witnessed an upward trend. Kearney and Poti [4] confirm this finding for the European stock markets.

A large body of literature underlines the fact that idiosyncratic volatility is not only relevant in predicting stock market returns and volatility, but it is also priced. Goyal and Santa Clara [5] show that aggregate idiosyncratic volatility has a significant predictive power on the market's rate of return. Taylor [6] reports that the inclusion of idiosyncratic volatility improves the quality of market volatility predictions. Fu [7] documents a significant positive relationship between idiosyncratic volatility and expected returns. Stocks with an elevated idiosyncratic risk get a higher return than stocks with low idiosyncratic risk. Accordingly, the analysis of the features that affect idiosyncratic volatility enhances portfolio managers' and corporate directors' decisions.

In this paper, we propose the $R \& D$ investment as a possible determinant of stock return volatility. $R \& D$ expenditures have grown over the last decades. A firm invests in $R \& D$ activities and offers new products and services to differentiate itself and mitigate competition. Empirical results show that R\&D investments, actually, create value for the firm. Some authors find a positive relationship between the stock returns or the market value of the US firms and the R\&D intensity (Griliches [8], Hirschey and Weygandt [9], Sougiannis [10], Lev and Sougiannis [11]). Hall and Oriani [12] find the same results for France. Other authors report that corporate announcements about new $R \& D$ investment generate positive abnormal returns (Chan, Martin and Kensinger [13] and Eberhart, Maxwell and Siddique [14]). However, many studies investigate the riskiness of $R \& D$ investments and find that $R \& D$ intensive firms are riskier than others (Chan, Lakonishok and Sougiannis [15], Kothari, Laguerre and Leone [16]).

This paper contributes to the literature by examining the relationship between $R \& D$ investment and stock return volatility. This analysis is performed within the context of the French market because as we know, this problem has been researched exclusively on the United States and studies on European markets barely exist. The analysis of the European context is useful for two reasons. First, US firms invest more in R\&D than their European counterparts (Moncada-Paterno-Castello [17] and Moncada-Paterno-Castello, Ciupagea, Smith, Tubke and Tubbs [18]). Second, the R\&D reporting reveals a difference between the USA and France. While US firms adopt R\&D expensing, IAS-IFRS accounting rules, adopted by French firms, they differently cover research costs and development costs. Research costs are expensed, when development costs could be capitalized under certain conditions (IAS 38). Lantz and Sahut [19] point out that R\&D capitalization seems to limit the information asymmetry between firms and exchange markets. Accordingly, the study of the relationship between stock volatility and R\&D investment for non US firms, such as the French firms seems to be relevant due to these structural and accounting differences. 
Stock volatility is positively related to the degree of information asymmetry encountering the firm's prospects and profits (Gennotte and Leland [20], Eden and Jovanovic [21]). R\&D investments are expected to generate higher information asymmetry than tangible investments (Aboody and Lev [22]). We will test the hypothesis that stock volatility increases with the $R \& D$ investment intensity. We focus our analysis on high tech firms. These firms are R\&D intensive and exhibit higher stock return volatility. Our empirical results provide strong evidence of the checked hypothesis, as for the US context. R\&D investments make the firms' stocks riskier. The differences in accounting rules and investment behavior do not matter. These results contribute to the literature on the determinants of idiosyncratic volatility and also on the market valuation of $\mathrm{R} \& \mathrm{D}$ expenditures. The implications and recommendations will be discussed later.

The paper is organized as follows. Section 2 presents the theoretical background on stock volatility, information asymmetry and R\&D. Section 3 provides empirical evidence on high tech firms. Section 4 develops the hypotheses. Section 5 presents and describes the sample and the research design. Section 6 evaluates the relationship between R\&D and stock return volatility. The last section is devoted to concluding remarks and recommendations.

\section{Theoretical background}

\section{1 - Volatility and information asymmetry}

Many studies investigate the nature of the relationship between stock volatility and asymmetric information. Theoretical models predict that stock return volatility increases as the degree of information asymmetry becomes higher. Gennotte and Leland [20] suggest that volatility excess and market crashes, such as the 1987 market crash, could be explained to a greater extent by the trades of uninformed investors in a context of information asymmetry. Attanasio [23] argues that in the presence of asymmetric information and risk aversion, the stock prices tend to be more volatile than in full information environment. Eden and Jovanovic [21] formalize a theoretical model that explains the excessive volatility in financial markets by fluctuation of the amount of public information over time.

Since the level of information asymmetry cannot be directly measured, empirical studies use different proxies to approximate it. Analyst coverage, analyst prediction error, analysts' prediction dispersion, institutional ownership and bid ask spread are commonly used to measure the level of information asymmetry.

Sahut, Gharbi and Othmani Gharbi [24] corroborate theoretical models and find that stock volatility is negatively related to the institutional ownership and analysts' analysts' coverage for French firms. They find that analysts and institutional investors can mitigate the asymmetric information problem and reduce stock volatility.

\section{2 - R\&D and information asymmetry}

All types of projects generate some degree of asymmetric information between the managers (the insiders), who possess detailed information about the productivity of individual assets, and investors (outsiders) who have global and inaccurate information (Aboody and Lev [22]). Hubbard [25] suggests that informational asymmetry related to R\&D investments is particularly important. Alam and Walton [26] indicate that the level of information asymmetry between managers and shareholders is higher for the firms with R\&D expenses compared to firms with no R\&D investments. Blazenko [27] shows that managers have more knowledge about the state and the outcome of R\&D activities compared to outsiders. Boone 
and Raman [28] report a positive and significant relationship between R\&D and bid ask spread. The bid ask spread increases with the level of information asymmetry.

R\&D investments are associated with higher information asymmetry than physical and financial ones for many reasons.

First, R\&D intensive firms have little incentive to disclose detailed information about their projects since they consider secrecy as an effective way to protect innovation and competitive advantage. Cohen, Nelson and Walsh [29] have examined the strategies of 1478 US R\&D laboratories in protecting their innovations and found that the firm's firm's secrecy is apparently much more practiced than patents, marketing and manufacturing complementary proficiencies.

Second, R\&D projects are unique for the firms which conduct the projects. Aboody and Lev [22] (p 2750) explained: "The relative uniqueness of R\&D investments makes it difficult for outsiders to learn about the productivity and value of a given firms' R\&D from the performance and products of other firms in the industry thereby contributing to information asymmetry". The lack of organized markets for R\&D projects worsens the problem.

Third, the accounting handling of $R \& D$ investment does not convey complete information about $R \& D$ valuation and profitability. Generally, $R \& D$ investments are never reported in the balance sheet but fully expensed in the profit and loss account, although, these expenditures can generate profits for several coming years and can be considered as assets (Oswald and Zarowin [30]). Franzen, Rodgers and Simin [31] report that accounting based distress measures tend to misclassify solvent firms as their R\&D spending increases.

Finally, $\mathrm{Gu}$ and Wang [32] present evidence that $\mathrm{R} \& \mathrm{D}$ expenditures are associated with higher analysts' analysts' prediction errors. Barth, Karzink and McNichols [33] found that analysts' earnings predictions dispersal is higher for R\&D intensive firms than other firms. Therefore, disagreement among investors results from the level of information asymmetry.

R\&D informational asymmetries adversely influence the financing decisions and the dividend policy. Firms encounter many difficulties to finance R\&D projects (Alam and Walton [26], Hubbard [25]). Himmelberg and Petersen [34] ascertain that firms tend to rely on internal finance to cover R\&D activities. Hall [35] finds that R\&D intensive firms avoid using debt to finance $R \& D$ activities.

According to the signaling approach to the dividend policy, Barth and Kasznik [36] point out that $\mathrm{R} \& \mathrm{D}$ intensive firms tend to repurchase shares to convey information about the good quality of their projects.

\section{3 - R\&D and firm's risks}

The R\&D uncertainty is substantially higher than that of tangible assets. R\&D investments develop many types of firms' firms' risks such as the risk of product failure, earnings variability, systematic risk, firms' firms' bond risk, and stock return volatility.

First, Mansfield and Wagner [37] show that intangible investments have a higher probability of failure than tangible investments.

Second, Kothari, Laguerre and Leone [16] find that earnings variability of R\&D investments is about three times higher than that on physical assets. Amir, Guan and Livne [38] conclude that $R \& D$ contributes more to the variability of subsequent operating income than physical assets. This result holds only in industries where $R \& D$ is relatively more intensive than physical capital.

Third, the empirical relationship between $R \& D$ and systematic risk yields contradictory results. Wedig [39] compares the systematic risk of $R \& D$ and non $R \& D$ firms and finds that $R \& D$ firms are riskier and that there is a significant systematic risk 
premium associated with R\&D. Lantz and Sahut [19] provide evidence that the Beta is twice higher for companies with intensive investment in $R \& D$ compared to low $R \& D$ investing companies. Ho, $\mathrm{Xu}$ and Yap [40] report a positive association between R\&D intensity and systemic risk whereas McAlister, Srinivasan and Kim [41] find that R\&D and advertising lower the firm's systematic risk.

Fourth, Shi [42] examines the tradeoff between the future benefits from R\&D and the riskiness from the perspective of bondholders. He finds that R\&D investments are positively associated with bond default risk and bond risk premium and that the risks associated with R\&D dominate the future benefits.

Fifth, Chan, Lakonishok and Sougiannis [15] find that R\&D intensity is positively associated with the volatility of stock returns. They indicate that return volatility for $R \& D$ intensive firms is about 2.21 percent higher than the return volatility for firms with

no R\&D. In a more recent paper, Fung [43] provide empirical evidence that R\&D and stock volatility are positively related in the US context. Chambers, Jennings and Thompson II [44] find that excess returns are highly variable for firms with higher R\&D levels. They define excess return as the difference between the realized return and the expected return from the Fama and French [45] model.

\section{Empirical evidence in high-tech firms}

\section{1 - Volatility of high-tech firms}

Many empirical results show that high tech firms are more volatile than low-tech firms. Pastor and Veronesi $[46,47]$ find that the ""new economy" stocks (high tech) are more volatile than "old economy" stocks. They explain this result by the uncertainty about the success and the profitability of new technology.

Schwert [48] finds that NASDAQ, which is dominated by high-tech stocks, is more volatile than S\&P index. Aggregate idiosyncratic volatility for Nasdaq firms is four times higher than that of NYSE/AMEX firms.

Nasdaq index increased from 329.,84 in October 1990 to 5132.,52 in March 2000, which represents about 1456.,057 percent increase in less than a decade. Then, the index declined to reach 1108.,48 in October 2002, which is a record of about 78.,4 percent in less than three years (Tseng [49]).

Mazzucato and Tancioni [50] analyze volatility in different sectors and find that semiconductors and electrical equipment in firms' stocks are more volatile than the S\&P index benchmark.

\section{2 - R\&D activities in high tech firms}

During the last decades, high tech industries have been changing rapidly. Agarwal and Gort [51] report that the required time for an idea to be materialized in a viable product was 33 years in 1900 and 3.4 years in 1967-1987. Ittner and Larcker [52] corroborate this result in the computer and automobile industries. According to them, the intensity of the competition in these sectors is so significant that it readily justifies such findings.

R\&D activities in high technology are particularly risky. Wetter [53] suggests that high tech firms face two additional risks compared to others firms. These firms have to create their own market for their new products. In addition, high tech firms may face the risk that their markets can be replaced by "alternate" technologies. Grabowski and Vernon [54] examine the returns 
and risks in the pharmaceutical R\&D and report that only 30 drugs out of 100 licensed drugs earned enough money to compensate for their R\&D costs.

\section{3 - Asymmetric information in high-tech firms}

The level of information asymmetry in high-tech firms is high due to the complexity and technicality of innovation. Liu [55] suggests that the innovation process in high technology industries consists of many stages with different sources of risk.

Accordingly, investors Investors tend to establish wrong predictions about the profitability of R\&D projects.

$\mathrm{Gu}$ and $\mathrm{Li}$ [56] suggest that managers of high tech firms may amplify the asymmetric information problem. Owing to rude competition, managers are incited to hide key or detailed information or to minimize the prospects of new products so as to discourage competition.

Many studies find that information asymmetry measures are more developed in high tech firms. $\mathrm{Gu}$ and Wang [32] find higher earnings prediction errors in high tech firms due to information complexity. Barron, Byard, Kile and Riedl [57] report that high tech firms are characterized by a low level of analysts' consensus because of the high R\&D intensity.

Tasker [58] shows that high tech firms organize conference calls and provide additional information to compensate for the low informativeness of their financial statements. Dell'Acque, Perrini and Caselli [59] indicate that the use of conference calls may reduce idiosyncratic volatility for high tech firms.

\section{4 - The empirical relationship between R\&D and stock volatility in high tech firms}

The financial literature provides formal empirical evidences that $R \& D$ expenditures and volatility are positively associated in the high tech industries. Mazzucato and Tancioni [50] find that the higher the firm's firm's R\&D intensity, the higher the idiosyncratic risk is.

$\mathrm{Xu}$ [60] report a positive and significant association between $R \& D$ investment in the development of new drugs and stock price volatility of pharmaceutical firms.

Schwert [48] suggests growth options of high tech firms such as R\&D and innovation can explain the higher volatility in NASDAQ. Cao, Simin, Zhao [61] corroborate this result and find that firms with high growth options are riskier.

\section{5 - Hypotheses development}

R\&D investments generate asymmetric information about their success probability, their nature, their prospects and their profits. Because stock return volatility increases with information asymmetry, we expect that it will increase with $R \& D$ investments.

In this study, we distinguish between total stock volatility and idiosyncratic stock volatility. Thus, we develop our first hypothesis which states that:

\section{Hypothesis (1)}

total stock return volatility is positively related to the R\&D investment intensity.

$R \& D$ investments are specific to the firm. Therefore, we expect that $R \& D$ is more associated with the idiosyncratic component of total volatility. Thus, we develop our second hypothesis which states that:

Hypothesis (2) 


\section{Sample and research design}

\section{1 - Sample}

Our initial sample includes the 162 French high-tech firms on Thomson Reuters that disclosed R\&D expenses during the period 2002-2011. We focus on firms in high technology industries, namely information technology, electrical and electronic

equipment and telecommunications. Firms in these sectors seem to have similar stock trading characteristics and R\&D behaviour. Our final sample consists of 1620 firms and yearly observations over the period 2002-2011.

\section{2 - Models and variables}

Given that the data are in a panel, we must examine the pooled regression, the fixed effects model and the random effects model to choose the appropriate specification.

The pooled regression imposes the same constant $\alpha$ for all firms. The model can be presented as follows:

$\mathrm{Y}_{\mathrm{it}}=\alpha+\beta^{\prime} \mathrm{X}_{\mathrm{it}}+\varepsilon_{\mathrm{it}}$

Where $Y_{\text {it }}$ is the dependent variable for firm i at time $t, \beta^{\prime}$ is a row vector of slope regressors, $\mathrm{X}_{\mathrm{it}}$ is a column vector of explanatory variables for firm $\mathrm{i}$ at time $\mathrm{t}$ and $\varepsilon_{\mathrm{it}}$ is a residual error of firm $i$ at time $t$.

The fixed effects model allows the constant to differ between firms but it is still time invariant. The coefficients $\alpha_{i}$ represent unobservable individual firm-specific effects. The model can be presented as follows:

$\mathrm{Y}_{\mathrm{it}}=\alpha_{\mathrm{i}}+\beta^{\prime} \mathrm{X}_{\mathrm{it}}+\varepsilon_{\mathrm{it}}$

For the random effect model, the constant is a random variable that can be written in the following form:

$\alpha=\alpha_{\mathrm{i}}+u_{\mathrm{i}}$

The random effects model is presented as follows:

$\mathrm{Y}_{\mathrm{it}}=\alpha+\beta^{\prime} \mathrm{X}_{\mathrm{it}}+u_{\mathrm{i}}+\varepsilon_{\mathrm{it}}$

To choose the appropriate specification, three tests have been conducted. The F-test examines the significance of the fixed effects. The Breush and Pagan [62] Lagrangian Multiplier examines the significance of the random effects. The Hausman test [63] compares the fixed and the random effects.

Our dependent variable relies on stock volatility. We consider two measures used separately. Total stock volatility (TV) is the annualized standard deviation of weekly returns for each year. Idiosyncratic stock volatility (IV) is the annualized standard deviation of weekly errors from the CAPM model for each year. We use weekly returns because they are supposed to contain less noise than daily returns, they eliminate the day of the week effect and they resolve the thin-trading problem. We make a logarithmic transformation on volatility measures to ensure that the stock volatility estimates are non-negative and to reduce both skewness and kurtosis of stock volatility distributions [5]. 
The total stock volatility measures the entire financial risk surrounding the firm's stock. It can be decomposed into systematic or market related risk and idiosyncratic or firm specific risk. We use this first measure to analyse the effect of $R \& D$ on firm financial risk.

R\&D investments are specific to the firm that engages them. The use of idiosyncratic volatility will permit us to focus on the impact of specific firm investment on firm specific risk.

Following Chambers, Jennings and Thompson II [44] and Chan, Lakonishok and Sougiannis [15] among others, we make use of the ratio of $R \& D$ expenses applied to sales in order to measure R\&D intensity.

Control variables, size and leverage are widely accepted as determinants of stock volatility. On the one hand, Christie [64] finds that the stock volatility increases with the leverage. The firm's firm's debt financing affects its future cash flows through interest payment and increases the probability of payment default. On the other hand, smaller firms exhibit higher volatility and asymmetric information because financial analysts have little incentive to cover their activities and prospects (Bhushan [65]).

Size is measured by the logarithm of market capitalisation and leverage is measured by the margin between the ratio of total debt and total assets. Stock returns, market capitalization, R\&D expenses, sales and leverage ratio are obtained from Thomson Reuters database. In order to reduce the effects of outliers on our results, we winsorize all the variables at both upper and lower levels at $1 \%$ of their distribution. Table 1 presents the variables' definitions and abbreviations.

\section{Table 1 - Definition of used variables}

\begin{tabular}{|l|l|l|}
\hline Variables & Abreviations & Definitions \\
\hline Total volatility & TV & $\begin{array}{l}\text { Annualized standard deviation of weekly } \\
\text { returns }\end{array}$ \\
\hline Idiosyncratic volatility & IV & $\begin{array}{l}\text { Annualized standard deviation of weekly } \\
\text { errors from the CAPM model }\end{array}$ \\
\hline R\&D intensity & SIZE & Ratio of R\&D expenses to sales \\
\hline Size leverage & LEVERAGE & $\begin{array}{l}\text { Natural logarithm of market capitalization } \\
\text { Ratio of total debts to total assets }\end{array}$ \\
\hline
\end{tabular}

\section{3 - Descriptive statistics}

Table 2 reveals the following remarks: the volatility measures are high. They are averaging $49.1 \%$ and $46.9 \%$ for total volatility and idiosyncratic volatility respectively. Volatility measures have high skewness and high kurtosis. Logarithm transformation reduces both skewness and kurtosis. The distributions of the transformed variables are much closer to the normal distribution. 
Table 2 - Descriptive statistics

\begin{tabular}{lccccccc}
\hline Variables & Mean & Median & Sd. & Min. & Max. & Skewness & Kurtosis \\
\hline TV & 0.491 & 0.421 & 0.293 & 0.068 & 1.842 & 2.061 & 8.830 \\
Ln(TV) & -0.854 & -0.864 & 0.536 & -2.688 & 0.611 & -0.057 & 3.939 \\
IV & 0.469 & 0.388 & 0.295 & 0.066 & 1.785 & 2.044 & 8.438 \\
Ln(IV) & -0.917 & -0.945 & 0.561 & -2.711 & 0.579 & 0.035 & 3.592 \\
R\&D & 0.107 & 0.059 & 0.192 & 0.000 & 1.66 & 5.841 & 44.486 \\
Leverage & 0.168 & 0.122 & 0.172 & 0.000 & 0.973 & 1.577 & 6.294 \\
Size & 18.075 & 17.515 & 2.347 & 11.063 & 24.321 & 0.727 & 3.060 \\
\hline
\end{tabular}

Note: See Table 1 for variable definitions.

R\&D intensity is relatively high for high tech industries firms. Firms invest on average $10.7 \%$ of their sales on R\&D. The standard deviation of this variable is also high, measured at $19.2 \%$. The R\&D intensity is variable over time and across firms.

\section{Empirical results}

Table 3 exposes Pearson correlations of volatility measures, R\&D intensity and control variables. Total and idiosyncratic volatilities and R\&D intensity are positively correlated, which in indicates that stock volatility increases with R\&D intensity.

Table 3 - Pearson correlation coefficients

\begin{tabular}{lccccc}
\hline Variables & Ln(TV) & Ln(IV) & R\&D & Leverage & Size \\
\hline Ln(TV) & 1 & & & & \\
Ln(IV) & $0.947^{* * *}$ & 1 & & & \\
R\&D & $0.216^{* * *}$ & $0.214^{* * *}$ & 1 & & \\
Leverage & 0.058 & 0.018 & $-0.083^{* *}$ & 1 & 1 \\
Size & -0.293 & $-0.428^{* * *}$ & $-0.088^{* *}$ & $0.169 * * *$ & 1 \\
\hline
\end{tabular}

Note: Asterisks indicate significance at the $1 \%\left({ }^{* * *}\right), 5 \%\left({ }^{* *}\right)$ and $10 \%\left({ }^{*}\right)$ levels in a two-tail test.

Along with previous research studies, volatility measures and size are negatively correlated. However, the correlations between volatility measures and leverage are insignificant positively correlated with correlation coefficients at about 0.947 . The correlations between independent variables are not sufficiently large to cause multicollinearity problems.

Table 4 presents the results on the relationship between total volatility and R\&D intensity. Ftest shows that fixed effects are significant since F-statistic is significant at a $1 \%$ level. The large value of the Breush--Pagan Lagrangian Multiplier confirms the significance of the random effects. To choose the appropriate specification, the Hausman test is conducted. The Hausman test statistic is significant at $1 \%$ level so the fixed effects model is preferred to the random effects model. 
Table 4 - Effects of R\&D intensity on the stock total volatility (In(TV))

\begin{tabular}{lccc}
\hline Independant variables & Pooled model & Fixed effects model & Random effects model \\
\hline Constant & 0.064 & $2.762^{* * * *}$ & $0.665^{* * *}$ \\
& $(0.464)$ & $(6.097)$ & $(2.930)$ \\
R\&D & $0.544 * * *$ & $0.393^{* * *}$ & $0.388^{* * *}$ \\
& $(6.095)$ & $(2.833)$ & $(3.615)$ \\
Leverage & $0.398^{* * *}$ & $0.299 * * *$ & $0.376^{* * *}$ \\
& $(3.761)$ & $(2.114)$ & $(3.128)$ \\
Size & $-0.058^{* * *}$ & $-0.202^{* * *}$ & $-0.091^{* * *}$ \\
& $(-7.833)$ & $(-8.325)$ & $(-7.452)$ \\
Adj-R ${ }^{2}$ & 0.140 & 0.513 & 0.094 \\
F-statistic & 5.744 & & \\
Breush Pagna LM test & 208.57 & & \\
Haussman test & 27.95 & & \\
\hline
\end{tabular}

Note: The numbers in the parentheses are standard errors. Asterisks indicate significance at the $1 \%\left({ }^{\star \star \star}\right), 5 \%\left({ }^{* \star}\right)$ and $10 \%\left({ }^{\star}\right)$ levels.

Table 5 presents the results about the relationship between idiosyncratic volatility and R\&D. According to the specification tests' results, the fixed effects specification is also preferable.

Table 5 - Effects of R\&D intensity on the stock idiosyncratic volatility (In(IV))

\begin{tabular}{lccc} 
Independant variables & Pooled model & Fixed effects model & Random effects model \\
\hline Constant & $0.596^{* * *}$ & $2.568^{* * *}$ & $1.055^{* * *}$ \\
& $(4.272)$ & $(5.709)$ & $(4.570)$ \\
R\&D & $0.508^{* * *}$ & $0.422^{* * *}$ & $0.385^{* * *}$ \\
& $(5.683)$ & $(3.066)$ & $(3.565)$ \\
Leverage & $0.354 * * *$ & $0.360^{* *}$ & $0.374^{* * *}$ \\
& $(3.338)$ & $(2.566)$ & $(3.105)$ \\
Size & $-0.090^{* * *}$ & $-0.195^{* * *}$ & $-0,116^{* * *}$ \\
& $(-12.126)$ & $(-8.153)$ & $(-9.312)$ \\
Adj-R ${ }^{2}$ & 0.223 & 0.569 & 0.130 \\
F-statistic & 5.984 & & \\
Breush Pagna LM test & 229.32 & & \\
\hline
\end{tabular}

Note: The numbers in the parentheses are standard errors. Asterisks indicate significance at the $1 \%\left({ }^{* *}\right), 5 \%\left({ }^{* *}\right)$ and $10 \%\left({ }^{*}\right)$ levels.

In the model with total stock volatility, the estimated coefficient of $R \& D$ is 0.393 . It is positive and significant at the $1 \%$ level. The adjusted R-squared is $51.3 \%$. Supporting H1, this result suggests that $R \& D$ intensity significantly increases the total stock volatility. This result corroborates Chan, Lakonishok and Sougiannis [15] and Fung [43] who document a positive relationship between total stock volatility and R\&D intensity in the U.S. context.

In the model with idiosyncratic volatility, the estimated coefficient is 0.422 . It is positive and significant at the $1 \%$ level. This finding supports $\mathrm{H} 2$ and suggests that idiosyncratic volatility is positively related to $\mathrm{R} \& \mathrm{D}$ intensity. The adjusted R-squared is 0.569 . These statistics are better than those of the total stock volatility model. R\&D activities are specific to the firm in which they are practiced and they further influence the idiosyncratic component of stock return volatility.

The results of control variables are consistent with theoretical predictions as well as previous empirical studies. Size is negatively significant, in accordance with the asymmetric 
information explanation provided by Bhushan [65] who suggests that analysts do not thoroughly cover small firms and that these companies exhibit higher information asymmetry. Leverage is positively significant, which matches the positive relationship documented in Christie [64] with a U.S. sample. Leverage makes firms stocks riskier.

\section{Conclusion}

The purpose of this paper is to examine the impact of R\&D investments on the stock return volatility in a European context, namely, France. The previous studies focused on the U.S. context where a positive relationship has been found. There are at least two major differences between U.S. and French firms in dealing with R\&D activities. First, U.S. firms invest more in R\&D. Second, U.S. firms expense R\&D while French firms expense research costs and capitalise development costs.

With a sample of French firms that invest in R\&D activities, we provide evidence that total stock volatility and idiosyncratic volatility are positively related to the $R \& D$ intensity. $R \& D$ activities increase the degree of information asymmetry about the firm's prospects and profits and they also make the firm's stock more volatile.

This finding contributes to the existent literature in two ways. First, R\&D intensity should be considered as a determinant of stock volatility. The growth of R\&D in the last decades could be considered as one plausible explanation of the upward trend in idiosyncratic volatility that many authors tried to explain since the seminal work of Campbell, Lettau, Malkiel and Xu [3]. Second, the difference in R\&D reporting between U.S.A. and France does not affect the relationship between $R \& D$ and stock volatility. $R \& D$ investment makes the firm's stock riskier under expensing or capitalizing policies.

This research has implications for corporate managers who should implement an efficient communication policy that can reduce information asymmetry about R\&D investment. Corporate managers should disclose information that reduces uncertainty about the product's success probability and the expected profits.

\section{References}

[1]

R.J. Shiller, Do stock prices move too much to be justified by subsequent changes in dividends, Am. Econ. Rev. 71 (3), 1981, 421-436.

[2]

G.W. Schwert, Why does stock market volatility change over time?, J. Financ. 44 (5), 1989, 1115-1153.

[3]

J.Y. Campbell, M. Lettau, B.G. Malkiel and Y. Xu, Have individual stocks become more volatile? An empirical exploration of idiosyncratic risk, J. Financ. 56 (1), 2001, 1-43.

[4]

C. Kearney and V. Poti, Have European stocks become more volatile? An empirical investigation of idiosyncratic and market risk in the Euro Area, Eur. Financ. Manag. 14 (3), 2008, 419-444.

[5]

A. Goyal and P. Santa Clara, Idiosyncratic risk matters!, J. Financ. 58 (3), 2003, 975-1007.

[6]

N. Taylor, Can idiosyncratic volatility help forecast stock market volatility?, Int. J. Forecast. 24 (3), 2008, 462-479.

[7]

F. Fu, Idiosyncratic risk and the cross-section of expected stock returns, J. Financ. Econ. 91 (1), 2009, 24-37.

[8]

Z. Griliches, Market value, R\&D and patents, Econ. Lett. 7 (2), 1981, 183-187.

[9]

M. Hirschey and J.J. Weygandt, Amortization policy for advertising and research and development expenditures, J. Account. Res. 23 (1), 1985, 326-335.

[10] 
T. Sougiannis, The accounting based valuation of corporate R\&D, Account. Rev. 69 (1), 1994, 44-68.

\section{[11]}

B. Lev and T. Sougiannis, The capitalization, amortization and value relevance of R\&D, J. Account. Econ. 21 (1), 1996, 107-138.

[12]

B.H. Hall and R. Oriani, Does the market value R\&D investment by European firms: evidence from a panel of manufacturing firms in France, Germany and Italy, Int. J. Ind. Organ. 24 (5), 2006, 971-993.

[13]

S.H. Chan, J.D. Martin and J.W. Kensinger, Corporate research and development expenditures and share value, J. Financ. Econ. 26 (2), 1990, 255-276.

[14]

A.C. Eberhart, W.F. Maxwell and A.R. Siddique, An examination of long-term abnormal stock returns and operating performance following R\&D increases, J. Financ. 59 (2), 2004, 623-650.

[15]

L.K.C. Chan, J. Lakonishok and T. Sougiannis, The stock market valuation of research and development expenditures, J. Financ. 56 (6), 2001, 2431-2456.

[16]

S.P. Kothari, T.E. Laguerre and A.J. Leone, Capitalization versus expensing: evidence on the uncertainty of future earnings from capital expenditure versus R\&D outlays, Rev. Account. Stud. 7 (4), 2002, 355-382.

[17]

P. Moncada-Paternò-Castello, Introduction to a special issue: new insights on EU-US comparison of corporate R\&D, Sci. Public Policy 37 (6), 2010, 391-400.

[18]

P. Moncada-Paternò-Castello, C. Ciupagea, K. Smith, A. Tübke and M. Tubbs, Does Europe perform too little corporate R\&D? A comparison of EU and non EU corporate R\&D performance, Res. Policy 39 (4), 2010, 523536.

[19]

J.S. Lantz and J.M. Sahut, R\&D investment and the financial performance of technological firms, Int. J. Bus. 10 (3), 2005, 251-270.

[20]

G. Gennotte and H. Leland, Market liquidity, hedging and crashes, Am. Econ. Rev. 80 (5), 1990, 999-1021.

[21]

B. Eden and B. Jovanovic, Asymmetric information and the excess volatility of stock prices, Econ. Inq. 32 (2), 1994, 228-235.

[22]

D. Aboody and B. Lev, Information asymmetry, R\&D and insider gains, J. Financ. 55 (6), 2000, 2747-2766.

[23]

O.P. Attanasio, Asset price volatility and information structures, Econ. Lett. 33 (2), 1990, 159-164.

[24]

J.M.Sahut, S. Gharbi and H. Othmani Gharbi, Stock volatility, institutional ownership and analyst coverage, Bankers Markets and Investors, 2011, 21-30, (110).

[25]

R.G. Hubbard, Capital-market imperfections and investment, J. Econ. Lit. 36 (1), 1998, 193-255.

[26]

P. Alam and K.S. Walton, Information asymmetry and valuation effects of debt financing, Financ. Rev. 30 (2), 1995, 289-311.

[27]

G.W. Blazenko, Managerial preference, asymmetric information and financial structure, J. Financ. 42 (4), 1987, 839-862.

[28]

J.P. Boone and K.K. Raman, Off-balance sheet R\&D assets and market liquidity, J. Account. Public Policy 20 (2), 2001, 97-128.

[29]

W.M.W. Cohen, R.R.Nelson and J.P. Walsh, Protecting their intellectual assets: appropriability conditions and why US Manufacturing firms patent (or not), In: NBER, Working Paper 7552, 2000.

[30]

D.R. Oswald and P. Zarowin, Capitalization of R\&D and the informativeness of stock prices, Eur. Account. Rev. 16 (4), 2007, 703-726.

[31]

L.A. Franzen, K.J. Rodgers and T.T. Simin, Measuring distress risk: the effect of R\&D intensity, J. Financ. 62 (6), 2007, 2931-2967.

[32]

F. Gu, W. Wang, Intangible assets, information complexity and analysts' earnings forecasts, J. Bus. Financ. Account. 32 (9-10), 2005, 1673-1702.

[33]

M.E. Barth, R. Kasznik and M.F. McNichols, Analyst coverage and intangible assets, J. Account. Res. 39 (1), $2001,1-34$. 
[34]

C. Himmelberg and B. Petersen, R\&D and internal finance: a panel study of small firms in high tech industries, Rev. Econ. Stat. 76 (1), 1994, 38-51.

[35]

B. Hall, Investment and research and development at the firm level: does the source of financing matter?, In: NBER Working Paper 4096, 1992.

[36]

M.E.M. E. Barth and R. Kasznik, share repurchases and intangible assets, J. Account. Econ. 28 (2), 1999, $211-$ 241.

[37]

E. Mansfield and S. Wagner, Organizational and strategic factors associated with probabilities of success in industrial research and development, J. Bus. 48 (2), 1975, 179-198.

[38]

E. Amir, Y. Guan and G. Livne, The association of R\&D and capital expenditures with subsequent earnings variability, J. Bus. Financ. Account. 34 (1-2), 2007, 222-246.

[39]

G.J. Wedig, How risky is R and D ? A financial approach, Rev. Econ. Stat. 72 (2), 1990, 296-303.

[40]

Y.K. Ho, Z. Xu and C.M. Yap, R\&D investment and systematic risk, Account. Financ. 44 (3), 2004, 393-418.

[41]

L. McAlister, R. Srinivasan and M. Kim, Advertising, research and development and systematic risk of the firm, J. Mark. 71 (1), 2007, 35-48.

[42]

C. Shi, On the trade-off between the future benefits and riskiness of R\&D: a bondholders' perspective, J. Account. Econ. 35 (2), 2003, 227-254.

[43]

M.K. Fung, R\&D, knowledge spillovers and stock volatility", Account. Financ. 46 (1), 2006, 107-124.

[44]

D. Chambers, , R. Jennings, and R.B. Thompson, II, Excess return to R\&D intensive firms, Rev. Account. Stud. 7 (2-3), 2002, 133-158.

[45]

E.F. Fama and K.R. French, Common risk factors in the returns on stocks and bonds, J. Financ. Econ. 33 (1), 1993, 3-56.

[46]

L. Pastor and P. Veronesi, Technological revolutions and stock prices, Am. Econ. Rev. 99 (4), 2009, 1451-1483.

[47]

L. Pastor and P. Veronesi, Was there a Nasdaq bubble in the late 1990s, J. Financ. Econ. 81 (1), 2006, 61-100.

[48]

G.W. Schwert, Stock volatility in the new millennium: how wacky is Nasdaq?, J. Monet. Econ. 49 (1), 2002, 3-26.

[49]

K.C. Tseng, Panorama of Nasdaq stock bubbles and aftermath, Am. Bus. Rev. 22 (2), 2004, 61-71.

[50]

M. Mazzucato and M. Tancioni, Innovation and idiosyncratic risk: an industry and firm level analysis, Ind. Corp. Chang. 17 (4), 2008, 779-811.

[51]

R. Agarwal and M. Gort, First-mover advantage and the speed of competitive entry, 1887-1986, J. Law Econ. 44

(1), 2001, 161-177.

[52]

C.D. Ittner and D.F. Larcker, Product development cycle time and organizational performance, J. Mark. Res. 34 (1), 1997, 13-23.

[53]

J.J.J. J. Wetter, The impact of research and development expenditures: the The relationship between total factor productivity and U.S. gross domestic product performance, The Springer Book Series on Innovation, Technology and Knowledge

Management 2011, Springer; New York, NY, 26.

[54]

H. Grabowski and J. Vernon, A new look at the returns and risks to pharmaceutical R\&D, Manag. Sci. 36 (7), 1990, 804-824.

[55]

Q. Liu, How good is good news? Technology depth, book to market ratio and innovative events, J. Account. Audit. Financ. 21 (3), 2006, 293-321.

[56]

F. Gu and J.Q. Li, The credibility of voluntary disclosure and insider stock transactions, J. Account. Res. 45 (4), 2007, 771-810.

[57]

O.E. Barron, D. Byard, C. Kile and E.J. Riedl, High technology intangibles and analysts forecasts, J. Account. Res. 40 (2), 2002, 289-312. 
[58]

S.C. Tasker, Bridging the information gap: quarterly conference calls as a medium for voluntary disclosure, Rev. Account. Stud. 3 (1-2), 1998, 137-167.

[59]

A. Dell'Acqua, F. Perrini and S. Caselli, Conference calls and stock price volatility in the Post-Reg FD Era, Eur. Financ. Manag. 16 (2), 2010, 256-270.

[60]

B. Xu, R\&D strategy and stock price volatility in the biotechnology industry, Rev. Account. Financ. 5 (1), 2005, $59-71$.

[61]

C. Cao, T. Simin and J. Zhao, Can growth options explain the trend in idiosyncratic risk?, Rev. Financ. Stud. 21 (6), 2008, 2599-2633.

[62]

T.S. Breush and A.R. Pagan, The Lagrange Multiplier test and its applications to model specification in econometrics, Rev. Econ. Stud. 47 (1), 1980, 239-253.

[63]

J.A. Hausman, Specification tests in econometrics, Econometrica 46 (6), 1978, 1251-1271.

[64]

A. Christie, The stochastic behavior of common stock variances: value, leverage and interest rate effects, J. Financ. Econ. 10 (4), 1982, 407-432.

[65]

R. Bhushan, Firm characteristics and analyst following, J. Account. Econ. 11 (2-3), 1989, 255-274. 